\title{
Simulating highly disturbed vegetation distribution: the case of China's Jing-Jin-Ji region
}

\author{
Sangui Yi ${ }^{1,2}$, Jihua Zhou ${ }^{1}$, Liming Lai ${ }^{1}$, Hui Du ${ }^{1}$, Qinglin Sun ${ }^{1,2}$, Liu Yang ${ }^{1,2}$, Xin Liu ${ }^{1,2}$, Benben Liu ${ }^{1,2}$, Yuanrun \\ Zheng Corresp. 1 \\ ${ }^{1}$ Key Laboratory of Resource Plants, West China Subalpine Botanical Garden, Institute of Botany, Chinese Academy of Sciences, Beijing, China \\ 2 University of Chinese Academy of Sciences, Beijing, China \\ Corresponding Author: Yuanrun Zheng \\ Email address: zhengyr@ibcas.ac.cn
}

Background. Simulating vegetation distribution is an effective method for identifying vegetation distribution patterns and trends. The primary goal of this study was to determine the best simulation method for a vegetation in an area that is heavily affected by human disturbance.

Methods. We used climate, topographic, and spectral data as the input variables for four machine learning models (random forest (RF), decision tree (DT), support vector machine (SVM), and maximum likelihood classification (MLC)) on three vegetation classification units (vegetation group (I), vegetation type (II), and formation and subformation (III)) in Jing-Jin-ji, one of China's most developed regions. We used a total of 2,789 vegetation points for model training and 974 vegetation points for model assessment.

Results. Our results showed that the RF method was the best of the four models, as it could effectively simulate vegetation distribution in all three classification units. The DT method could only simulate vegetation distribution in units I and II, while the other two models could not simulate vegetation distribution in any of the units. Kappa coefficients indicated that the DT and RF methods had more accurate predictions for units I and II than for unit III. The three vegetation classification units were most affected by six variables: three climate variables (annual mean temperature, mean diurnal range, and annual precipitation), one geospatial variable (slope), and two spectral variables (Mid-infrared ratio of winter vegetation index and brightness index of summer vegetation index). Variables Combination 7 , including annual mean temperature, annual precipitation, mean diurnal range and precipitation of driest month, produced the highest simulation accuracy.

Conclusions. We determined that the RF model was the most effective for simulating vegetation distribution in all classification units present in the jing-jin-ji region. The RF model produced high accuracy vegetation distributions in classification units I and II, but relatively low accuracy in classification unit III. Four climate variables were sufficient for vegetation distribution simulation in such region. 
1 Simulating highly disturbed vegetation distribution:

2 the case of China's Jing-Jin-Ji region

3

4

5

6

\author{
Sangui $\mathrm{Yi}^{1,2}$, Jihua Zhou ${ }^{1}$, Liming Lai ${ }^{1}$, Hui Du${ }^{1}$, Qinglin Sun ${ }^{1,2}$, Liu Yang ${ }^{1,2}$, Xin Liu ${ }^{1,2}$, \\ Benben Liu ${ }^{1,2}$, Yuanrun Zheng ${ }^{1, *}$ \\ ${ }^{1}$ Key Laboratory of Resource Plants, West China Subalpine Botanical Garden, Institute of \\ Botany, Chinese Academy of Sciences, Xiangshan, Beijing, China \\ ${ }^{2}$ University of Chinese Academy of Sciences, Beijing, China
}

Corresponding Author:

Yuanrun Zheng ${ }^{1, *}$

Xiangshan, Beijing, China

Email address: zhengyr@ibcas.ac.cn

\title{
Abstract
}

Background. Simulating vegetation distribution is an effective method for identifying vegetation distribution patterns and trends. The primary goal of this study was to determine the best simulation method for a vegetation in an area that is heavily affected by human disturbance. Methods. We used climate, topographic, and spectral data as the input variables for four machine learning models (random forest (RF), decision tree (DT), support vector machine (SVM), and maximum likelihood classification (MLC)) on three vegetation classification units (vegetation group (I), vegetation type (II), and formation and subformation (III)) in Jing-Jin-Ji, one of China's most developed regions. We used a total of 2,789 vegetation points for model training and 974 vegetation points for model assessment.

Results. Our results showed that the RF method was the best of the four models, as it could effectively simulate vegetation distribution in all three classification units. The DT method could only simulate vegetation distribution in units I and II, while the other two models could not simulate vegetation distribution in any of the units. Kappa coefficients indicated that the DT and RF methods had more accurate predictions for units I and II than for unit III. The three vegetation classification units were most affected by six variables: three climate variables (annual mean temperature, mean diurnal range, and annual precipitation), one geospatial variable (slope), and two spectral variables (Mid-infrared ratio of winter vegetation index and brightness index of summer vegetation index). Variables Combination 7, including annual mean temperature, annual precipitation, mean diurnal range and precipitation of driest month, produced the highest simulation accuracy.

Conclusions. We determined that the RF model was the most effective for simulating vegetation distribution in all classification units present in the Jing-Jin-Ji region. The RF model produced high accuracy vegetation distributions in classification units I and II, but relatively low accuracy 
40 in classification unit III. Four climate variables were sufficient for vegetation distribution

41 simulation in such region.

42

43 Introduction

44 Vegetation is an essential component of terrestrial ecosystems and landscapes (Editorial

45 Committee of Vegetation Map of China, Chinese Academy of Science, 2007). Environmental

46 research, resource management, and conservation planning require vegetation distribution maps

47 (Franklin, 2010) to better understand, use, and monitor vegetation. Vegetation patterns and

48 distributions are affected by the climate (Chen et al., 2015; Zhang et al., 2018) and other

49 disturbances, particularly those caused by changes in land use (Hansen et al., 2013; Wehkamp et

50 al., 2018). Human disturbances, such as industrialization, urbanization, population growth, land

51 use change for agricultural use, etc., strongly influence the environment by greatly altering

52 vegetation patterns, making exact mapping a significant challenge (Xie, Sha, \& Yu, 2008; Zhou

53 et al., 2016).

54 Field surveys, the traditional method used to map vegetation, are costly and labor-intensive (Newell \& Leathwick, 2005; Zhou et al., 2016). Mapping using remote sensing data is also a popular method that has been used over the last 30 years (Xie, Sha, \& Yu, 2008). This method makes it possible to obtain a wide range of reliable data from remote sensing images, and it updates vegetation boundaries by visually interpreting images and field surveys (Zhang et al., 2008). However, determining vegetation units and their boundaries by visual interpretation can produce inaccurate results. Researchers may get different results from the same images for the same study areas (Bie \& Beckett, 1973; Pfeffer, Pebesma, \& Burrough, 2003). Furthermore, field survey and remote sensing methods manually draw vegetation unit boundaries based on climate, elevation, and soil type information, which can be inaccurate in transition areas (Zhang et al., 2008). Using simulation models in combination with field and remote sensing data may be an effective alternative for mapping vegetation.

Changes in the environment can affect vegetation composition, structure, function, and spatial distribution. Environmental variables have been used to simulate the global distribution of vegetation (Dilts et al., 2015; Mod et al., 2016). Simulation models are usually developed to test how environmental variables control vegetation distribution (Guisan \& Zimmermann, 2000). Modern remote sensing data and software make it more convenient than ever before to produce predictive vegetation maps (Franklin, 1995).

Predictive vegetation mapping uses environmental variables and various models based on niche theory and gradient analysis to visualize communities in geographic space (Dilts et al., 2015, Lany et al., 2019). Other methods based on statistics and machine learning have also been used to simulate vegetation distribution. Predictive vegetation mapping includes various statistical methods such as the generalized linear model, the generalized additive model, and multivariate statistical approaches (Lany et al., 2019; Prasad, Iverson, \& Liaw, 2006). Recently, machine learning modeling methods have been used to map the distribution of both vegetation 
80 decision tree (DT), and artificial neural network (Guisan \& Zimmermann, 2000; Hastie,

81 Tibshirani, \& Friedman, 2009; Zhou et al., 2016). These machine learning models have fewer

82 limitations and can produce more reliable results than traditional vegetation modeling methods

83 (Hastie, Tibshirani, \& Friedman, 2009). Advanced machine learning techniques can integrate

84 spectral and spatial predictors and improve classification accuracy by retaining important

85 information about vegetation composition and structural differences (Sesnie et al., 2010).

86 Machine learning models efficiently and cost-effectively produce vegetation maps without the

87 general inaccuracies caused by visual interpretation (Franklin, 2010).

88 The Jing-Jin-Ji region, also known as the Beijing-Tianjin-Hebei urban agglomeration, is the

89 center of northern Chinese politics, culture, and economy. Because of its extension, it faces

90 significant problems such as unbalanced regional development and the struggle between

91 economic growth and limited resources. The region's larger cities, including Beijing and Tianjin,

92 have large populations, developed economies, and abundant educational resources. However,

93 these big cities face issues of limited natural resources and serious ecological and environmental

94 pollution. In particular, Beijing's large population requires limited resources such as water, land,

95 and vegetation (Wang \& Gong, 2018). Breaking up administrative divisions may be the best

96 method to coordinate regional development (Wang et al., 2019). The new Xiong'an area located

97 in Hebei province is being constructed to relocate some of Beijing's population. The

98 development of areas like Xiong'an is affected by the surrounding natural environment. To better

99 integrate the environmental carrying capacity and socioeconomic development of the Jing-Jin-Ji

100 region, including the new Xiong'an area, accurate vegetation maps with temporal resolution are

101 necessary. The most updated vegetation map of the Jing-Jin-Ji region is the Vegetation Map of

102 the People's Republic of China (VMC), with a scale of 1:1,000,000 (Editorial Committee of

103 Vegetation Map of China, Chinese Academy of Science, 2007). Most of its data come from a

104 field survey conducted between 1980 and 1990, meaning its temporal and spatial scales are both

105 outdated.

106 In this study, we integrated geospatial, climate, and spectral data to simulate vegetation

107 distribution through four different models across three vegetation classification units. This

108 research was different from the research of Zhou et al. (2016). Firstly, the research area of this

109 research was the Jing-Jin-Ji region located in the North China Plain and affected by high social-

110 economic disturbance, while the Qilian Mountain in the research of Zhou et al. is characterized

111 by complex terrain, but without high social-economic disturbance. Secondly, the predictive

112 variables as well as the combinations of these variables were different from the research of Zhou

113 et al. (2016). Thirdly, we compared four model methods for simulating distribution of vegetation

114 in three vegetation classification levels, while only three models were used for simulation in two

115 vegetation classification levels in the research of Zhou et al. (2016). Our primary objectives were

116 to: (1) determine the best modeling method for vegetation affected by high socioeconomic

117 disturbance, (2) create an improved vegetation map of the Jing-Jin-Ji region, (3) determine the

118 predictive abilities of different models across different vegetation classification units, and (4)

119 determine which variables enhanced the classification accuracy for vegetation mapping. 
121

122

123

124

125

126

127

128

129

130

131

132

133

134

135

136

137

138

139

140

141

142

143

144

145

146

147

148

149

150

151

152

153

154

155

156

157

158

159

\section{Materials \& Methods}

\section{Study area}

The Jing-Jin-Ji region is located in the northern part of the North China Plain. Its location ranges from $113^{\circ} 04^{\prime}$ to $119^{\circ} 53^{\prime} \mathrm{E}$ and $36^{\circ} 01^{\prime}$ to $42^{\circ} 37^{\prime} \mathrm{N}$ and is bordered by Taihang Mountain in the west, Yanshan Mountain in the north, and the Bohai Sea in the east. The region includes the Beijing, Tianjin, and Hebei provinces (Fig. 1). Jing-Jin-Ji has a population of approximately 110 million people and covers an area of approximately $216,000 \mathrm{~km}^{2}$ (Wang et al., 2019). The region is a temperate monsoon climate zone with an elevation range of -14 to $2,837 \mathrm{~m}$ (Fig. 1). The annual precipitation ranges from 305 to $711 \mathrm{~mm}$, with increased precipitation at lower altitudes. The annual mean temperature ranges from -3 to $14^{\circ} \mathrm{C}$, with colder averages at higher elevations. The amount of precipitation in the region gradually decreases moving from the southeast to the northwest, while temperature changes show the reverse pattern.

\section{Vegetation and training data}

The VMC, completed in 2007 based on field survey data, included eight vegetation groups (I), 15 vegetation types (II), and 75 formations and subformations (III) from the Jing-Jin-Ji region. However, some of the map's vegetation unit areas are very small and difficult to distinguish. To ensure that enough training and assessment point data can be randomly selected in units II and III, we selected eight units I, 12 units II, and 39 units III from the study area (Table 1).

Cultivated vegetation are mainly distributed in low areas with an altitude range of -14 to $254 \mathrm{~m}$ and an annual mean temperature range of 7 to $14^{\circ} \mathrm{C}$. Major cultivated plants include winter wheat and coarse grains. Scrub and grass-forb communities are mainly distributed in the north, in elevations ranging from 254 to $1,440 \mathrm{~m}$.

We obtained model training and assessment data on vegetation composition from field surveys and other publications. We collected a total of 3,763 vegetation points, with 2,789 of those used for model training and 974 used for model assessment. Each unit III had at least 80 vegetation points, with at least 60 of those used for model training and 20 used for model assessment. The model training and assessment data were randomly selected for each unit III. Additionally, we increased the credibility of the model assessment by first rasterizing the vector VMC onto the same grid as the modeled data, and then assessing the data using the Kappa coefficient (Landis \& Koch, 1977; Weng \& Zhou, 2006; Zhou et al., 2016).

\section{Geospatial, climate, and spectral data}

We derived geospatial variables, including elevation, slope, and aspect, from the $30 \mathrm{~m}$ resolution Shuttle Radar Topography Mission (SRTM) digital elevation model (DEM; Zhao et al., 2018).

We then resampled these data to a $500 \times 500 \mathrm{~m}$ grid cell size using the cubic technique in ArcGIS 10.3 (Wu et al., 2019).

We downloaded the climate data, including 19 bioclimatic variables, at $\sim 1 \mathrm{~km}$ resolution from WorldClim (Fick \& Hijmans, 2017) at http://worldclim.org/. These climate data were also 
160

161

162

163

164

165

166

167

168

169

170

171

172

173

174

175

176

177

178

179

180

181

182

183

184

185

186

187

188

189

190

191

192

193

194

195

196

197

198

199

resampled to a $500 \times 500 \mathrm{~m}$ grid cell size using the cubic technique in ArcGIS 10.3 (Wu et al., 2019). Climatic variables are important for plant ecophysiology (Mod et al., 2016) and are commonly used as bioclimatic limits in vegetation models (Sitch et al., 2003).

We acquired the MYD09A1500M product data (sinusoidal projection, path 4 and row 26, path 4 and row 27, path 5 and row 26, path 5 and row 27) from summer (July 20, 2013) and winter (January 17, 2013) as Modis images from the Geospatial Data Cloud at http://www.gscloud.cn/. Our image pre-processing included image subset mosaicking and clipping in ENVI 5.2 (Deng, 2010). We obtained the land surface albedo in bands 1-7 directly from the MYD09A1500M product, and calculated the indices' effectiveness at reflecting vegetation information (Price, Guo, \& Stiles, 2002; Zhou et al., 2016).

Since vegetation indices can provide information on both vegetation and environment (Bannari, Morin, \& Bonn, 1995), these indices are more sensitive than single spectral bands at detecting green vegetation (Bannari, Morin, \& Bonn, 1995; Cohen \& Goward, 2004). Therefore, vegetation indices can be used for image interpretation, vegetation discrimination and prediction, and land use change detection (Bannari, Morin, \& Bonn, 1995; Cohen \& Goward, 2004; Zhou et al., 2016). We tested the vegetation discrimination of 14 vegetation indices (Table 2).

To determine the distribution predictive ability of different variables, we grouped the variables into different combinations based on the results of the Pearson correlation. We only used less correlated variables $(\mathrm{R}<|0.7|$, Pearson correlation) (Chala et al., 2017) in Combinations 1-9 (Table 3), then used variable combinations as input predictor variables to simulate vegetation distribution. Combination 1 included the less correlated variables of the summer land surface albedos from bands 1 to 7 . Combination 2 included the less correlated variables of the winter land surface albedos from bands 1 to 7 . Combination 3 included the less correlated variables in Combinations 1 and 2. Combination 4 included the less correlated variables of the summer vegetation indices. Combination 5 included the less correlated variables of the winter vegetation indices. Combination 6 included the less correlated variables in Combinations 4 and 5. Combination 7 included the less correlated variables from the 19 bioclimatic variables.

Combination 8 included the less correlated variables from the 19 bioclimatic variables and three geospatial variables. Combination 9 included the less correlated variables in Combinations 3, 6, and 8 . Combinations 10 and 11 represented the top 10 most important variables of the DT and RF methods, with Combination 9 in vegetation unit I, respectively (Table 3). The SVM and maximum likelihood classification (MLC) methods only output the simulation results of variable Combinations 1 to 6, likely due to the training samples' weak separability (Deng, 2010).

\section{Vegetation distribution models}

We used DT, RF, MLC, and SVM vegetation distribution models in this study. The DT model is a divisive, monothetic, and supervised classifier often used for species distribution modeling and related applications (Franklin, 2010). It is computationally fast and easy to understand and implement. It uses classification or regression algorithms to generate classification rules, and then visualizes those rules into simple tree graphics (Hastie, Tibshirani, \& Friedman, 2009; Zhou 
200

201

202

203

204

205

206

207

208

209

210

211

212

213

214

215

216

217

218

219

220

221

222

223

224

225

226

227

228

229

230

231

232

233

234

235

236

237

238

239

et al., 2016). The DT model calculates the most significant variables contributing to the model (Deng, 2010). We used a DT with five layers, 40 samples in the smallest parent node, and 10 samples in the smallest child node.

The RF model is an ensemble method that has been applied in risk assessment and species distribution modeling studies (Cutler et al., 2007; Zhang \& Dong, 2017). The RF model creates and combines different DTs to produce considerably more accurate classifications that are unaffected by noise or overtraining (Burai et al., 2015; Cutler et al., 2007; Gislason, Benediktsson, \& Sveinsson, 2006). The RF model also calculates the most significant variables that contribute to the model (Cutler et al., 2007). Running an RF model requires defined parameters, including tree number, number of randomly selected features, and node impurity function. We generated the RF model in EnMAP-Box, a license-free and platform-independent software interface designed to process hyperspectral remote sensing data, which was developed by the Humboldt University of Berlin. There are in-built applications aimed at the processing of hyperspectral data, such as SVM and RF for classification of image data in the EnMAP-Box (Held et al., 2014). We used the default settings in EnMAP-Box with 100 trees. The number of randomly selected features was equal to the square root of the number of all features, and we used a Gini coefficient for the node impurity function (Jakimow et al., 2014; Ma, Gao, \& Gu, 2019; van der Linden et al., 2015; Zhou et al., 2016).

The MLC model is one of the most commonly used supervised image classification methods. MLC's classification rules use the statistics of the Gaussian probability density function to assign each pixel to the class with the highest probability. Although the MLC method usually generates similar or more accurate classifications than other methods, it is not applicable when there are fewer training samples than input predictors (Burai et al., 2015; Zhou et al., 2016).

The SVM model is a supervised machine learning model used for classification and regression. It is a complex and widely used method that can output more accurate predictions (Burai et al., 2015) than other methods. The SVM model searches for an optimal plane in a multidimensional space to divide all sample elements into two categories, making the distance between the closest points in the two classes as large as possible (Kabacoff, 2016). Running an SVM model requires a defined kernel parameter $\mathrm{g}$ and regularization parameter $\mathrm{c}$. In this study, we generated the SVM model in the EnMAP-Box. The default settings in EnMAP-Box to the SVM model was applied, where the parameter $\mathrm{g}$ was 0.01 to 1,000 , and the parameter c was 0.1 to 1,000. Parameters $g$ and $\mathrm{c}$ were tested using a grid search with internal performance estimation, and we used those with the best performance for data training (Lin et al., 2014; van der Linden et al., 2014; van der Linden et al., 2015).

We generated the predicted vegetation maps of the three classification units using the DT, RF, MLC, and SVM methods with a resolution of $500 \mathrm{~m}$. We selected all 11 variable combinations as the input variables for each method. The DT and RF method results indicated which variables were most important for vegetation discrimination.

\section{Model assessment}


240 We used the VMC and a total of 974 vegetation points to assess the overall accuracy and Kappa 241 coefficient of every predicted vegetation map. Kappa coefficient values ranging from 0.4 to 0.55

242 indicated moderate agreement, from 0.56 to 0.8 indicated substantial agreement, and from 0.81

243 to 1 indicated almost perfect agreement (Landis \& Koch, 1977; Weng \& Zhou, 2006; Zhou et al., 244 2016). When the Kappa coefficient value was greater than 0.4, the assessed predicted map was

245 considered acceptable.

246

247 Results

248 Unit I modeling and assessment

249 The RF model's results were better than the results of the DT, MLC, and SVM models (Table 4).

250 The RF model had a Kappa coefficient larger than 0.4 when using variable Combinations 6 to 11

251 assessed by field point data, with an overall accuracy of $50 \%$ to $72 \%$. The RF model had a

252 Kappa coefficient larger than 0.56 when using variable Combinations 7 to 11 assessed by field

253 data, with an overall accuracy of $68 \%$ to $72 \%$. The RF model had the highest Kappa coefficient

254 of 0.66 and the highest overall accuracy of $72 \%$ when using variable Combination 7 . The DT

255 model had a Kappa coefficient larger than 0.4 when using variable Combinations 7 to 11

256 assessed by field point data, with an overall accuracy of 54\% to $56 \%$. The DT model had no

257 Kappa coefficient larger than 0.56 when using all variable combinations. After VMC assessment,

258 we found the highest Kappa coefficient was 0.38 with an overall accuracy of $57 \%$ in the RF

259 model using variable Combinations 9 to 11 (Table 4; Fig. 2).

260

261

Unit II modeling and assessment

262 The RF model results were better than the results of the other three models. The RF model using 263 variable Combinations 7 to 11 had a Kappa coefficient larger than 0.4, with overall accuracies of 264 66\%-70\% and 54\%-55\% for field point data and VMC assessments, respectively. The RF model 265

266

267

268

269

270

271

272

273

274 using Combinations 7 to 11 had a Kappa coefficient larger than 0.56 and an overall accuracy of $66 \%-70 \%$ when assessed by field point data. The RF model had the highest Kappa coefficient of 0.65 and the highest overall accuracy of $70 \%$ when using variable Combination 7 . The DT model using variable Combinations 7 to 11 had a Kappa coefficient larger than 0.4 , with overall accuracies of 53\%-55\% and 65\%-72\% for field point data and VMC assessments, respectively. The DT model had the highest Kappa coefficient of 0.54 and overall accuracy of $72 \%$ when using variable Combination 7. The DT model had a larger Kappa coefficient and greater overall accuracy when assessed by VMC rather than the RF model (Table 5; Fig. 3).

nit III modeling and assessment

275 Only the RF model could simulate vegetation distribution in unit III. The RF model using 276

277 variable Combinations 7 to 11 had a Kappa coefficient larger than 0.4 and an overall accuracy of $55 \%-58 \%$ assessed by field point data. The RF model using variable Combination 7 had the 278 highest Kappa coefficient of 0.57 (the only model with a Kappa coefficient larger than 0.56 ) and 
279 the highest overall accuracy of $58 \%$ assessed by field point data. The Kappa coefficients in all 280 models were less than 0.4 when assessed by the VMC (Table 6; Fig. 4).

281

282

283

284

285

286

287

288

289

290

291

292

293

294

295

296

297

298

299

300

301

302

303

304

305

306

307

308

309

310

311

312

313

\section{Important variables}

For the RF model, eight of the top 10 most important variables were the same across the different vegetation units: three climate variables (annual mean temperature, mean diurnal range, and annual precipitation), one geospatial variable (slope), and four spectral variables (Mid-infrared ratio and NDVI of winter vegetation index, brightness index and NDVI of summer vegetation index). For the DT model, nine of the top 10 most important variables were the same across the different vegetation units: four climate variables (annual mean temperature, mean diurnal range, precipitation of the driest month, and annual precipitation), one geospatial variable (slope), and 4 spectral variables (Mid-infrared ratio of winter vegetation index, brightness index of summer vegetation index, summer surface albedo of band 1, winter surface albedo of band 6) (Table 7).

\section{Discussion}

\section{Vegetation classification units}

Vegetation classification is an important and complex system with multiple levels. Higher level classification methods not only accurately classify vegetation, but they can also describe ecosystem diversity, even during global changes (Faber-Langendoen et al., 2014). Plants in different vegetation classification units have different spectral characteristics and climatic conditions that are the basis for vegetation distribution simulation. Thus, models using the same variables to simulate the vegetation distribution of different classification units may produce different classification accuracies (Dobrowski et al., 2008; Prasad, Iverson, \& Liaw, 2006). Map accuracy has been found to be a function of which classification system and categories are used (Muchoney et al., 2000).

Previous studies have explored vegetation distribution simulation using different vegetation classification systems. Plant functional types (PFTs), defined as plant sets sharing similar perturbation response effects on dominant ecosystem processes, have been used to simulate vegetation distribution, as seen in the Biome and Box system models (Box, 1981; Box, 1996; Dormann \& Woodin, 2002) with positive simulation results (Box, 1981; Song, Zhou \& Ouyang, 2005; Weng \& Zhou, 2006). The Mapped Atmosphere-Plant-Soil System (MAPSS) model was also used to simulate vegetation distribution using vegetation life forms, leaf area index, leaf morphology, and leaf longevity (Zhao et al., 2002). Other researchers studied potential vegetation distribution using the Holdridge life zone model, with positive vegetation pattern results (Zheng et al., 2006). When the IGBP classification system was applied to simulate vegetation distribution at a regional scale, the map estimate accuracy was upwards of $80 \%$ (Muchoney et al., 2000). In this study, we used machine learning models and a hierarchical classification system from the VMC to determine the best modeling method for vegetation affected by high socioeconomic disturbance at various classification levels. In the VMC, unit I was the highest classification level, mainly based upon community appearance; unit II was the 
319

320

321

322

323

324

325

326

327

328

329

330

331

332

333

334

335

336

337

338

339

340

341

342

343

344

345

346

347

348

349

350

351

352

353

354

355

356

357

358

second highest level, mainly based upon community and climate appearance; and unit III was the medium classification level, based upon the dominant species. The accuracy of the vegetation distribution simulations in units I and II was similar to each other and higher than unit III's simulation (Tables 4-6).

\section{Different model performances}

We were interested in vegetation distribution modeling's ability to forecast and respond to environmental changes and vegetation pattern management at local to global scales. Vegetation distribution predictions can help explain the relationship between plants and their abiotic and biotic environments (Franklin, 2010). To benefit from ecosystem service functions, people can design vegetation distributions according to distribution and abundance patterns and trends (Hastie, Tibshirani, \& Friedman, 2009). Vegetation classification has become a widely used ecological method due to a number of new statistical and machine learning methods used alongside mapped biological and environmental data to model vegetation distributions over large spatial scales at higher resolutions (Cutler et al., 2007). Different image classification methods are rarely used together in the same classification research, especially when combined with environmental variables (Li et al., 2014).

In this study, the RF model performed better than the DT, SVM, and MLC models across the three classification levels. This finding was consistent with the results of other studies that found that the RF method modeled vegetation distribution better than other methods (Prasad, Iverson, \& Liaw, 2006). The DT model divided the data into homogenous subgroups according to the range of predictor variable values. The DT model was generally able to handle a large number of independent variables and could build a tree model faster than the other methods. However, the DT model was somewhat unstable for vegetation distribution modeling and had lower classification accuracy (Zhou et al., 2016). The RF model generated a large number of independent trees through data subsets and developed a split in every tree model using a random subset of predictor variables. Therefore, we concluded that the RF model was generally better than the DT model. The SVM model was developed from statistical learning methods and discriminated class samples by locating potentially nonlinear or multiple linear boundaries between individual training points (Burai et al., 2015). The aim of the MLC model was to maximize the overall probability that a pixel is correctly assigned to a class. However, the MLC model requires a large number of training samples that limits its application (Sesnie et al., 2010). Previous research has shown that classification accuracies when using the SVM classifier were higher than the MLC model (Pal \& Mather, 2005; Boyd, Sanchez-Hernandez, \& Foody, 2006; Sanchez-Hernandez, Boyd, \& Foody, 2007; Sesnie et al., 2010). Because the model had fewer requirements, the DT method provided significantly more accurate classifications than those of the MLC model (Boyd, Sanchez-Hernandez, \& Foody, 2006). Other studies found that the RF and SVM models were similarly accurate (65.3\% and 66.6\%, respectively) (Sesnie et al., 2010), and that the RF, MLC, DT, and SVM models performed similarly and reasonably well when simulating land use classification (Li et al., 2014). In addition to the methods mentioned above, 
359

360

361

362

363

364

365

366

367

368

369

370

371

372

373

374

375

376

377

378

379

380

381

382

383

384

385

386

387

388

389

390

391

392

393

394

395

396

397

398

an artificial neural network implemented at a regional scale produced classification accuracies of $60 \%-80 \%$ (Muchoney et al., 2000; Haslem et al., 2010). In the Arctic, this method provided the most accurate vegetation mapping (Langford et al., 2019). The reasons for the similarly positive results of these models may be due to the relatively large differences between classification objects, and their use of sufficiently representative training samples and appropriate input variables. In our study, only the SVM and MLC models' output simulated the results of variable Combinations 1 to 6 . This may be due to the poor separability of the training samples, as the models could not recognize the training points or their vegetation categories (Jarnevich et al., 2015). The Jing-Jin-Ji region has many types of vegetation with very small distribution areas, so the selected training points may have been insufficient. Future training points for these vegetation types should be selected using field surveys, and more suitable models for modeling global vegetation distribution should be developed and tested (Jiang et al., 2012).

\section{Important variables in vegetation classification models}

Variable selection is directly related to the vegetation distribution model's ability to capture important environmental factors (Mod et al., 2016). Models predict the important variables that drive the distribution of vegetation (Prasad, Iverson, \& Liaw, 2006). Vegetation distribution is predominantly driven by temperature, precipitation, and topographical variables (Franklin, 1995; Mod et al., 2016; Prasad, Iverson, \& Liaw, 2006), specifically those related to physiological tolerance, site energy, and moisture balance (Franklin, 1995). In addition to environmental variables, some spectral variables are used as input variables. However, the overuse of spectral variables can actually decrease discrimination accuracy, meaning that only spectral variables reflecting vegetation information should be selected, such as those related to the visible spectrum, infrared spectrum, and vegetation indices (Price, Guo, \& Stiles, 2002, Zhou et al., 2016). Different variables respond to different information. Spectral variables directly reflect land surface object information, while geospatial and climatic variables reveal information about the vegetative environment.

Terrain, an important variable in vegetation distribution models, has long been used to improve map accuracy, especially for regions with large elevation differences (Dobrowski et al. 2008; Oke \& Thompson, 2015). Sesnie et al. (2010) found that adding elevation as a predictive variable dramatically improved the accuracies of the SVM and RF models $>80 \%$ for most forest types. Slopes with similar elevations but different aspects have very different soil and vegetation temperatures (Gunton, Polce, \& Kunin, 2015; Mod et al., 2016). Dobrowski et al. (2008) highlighted the importance of slope and aspect when mapping vegetation communities in the Sierra Nevada. Slope was also an important variable in this study (Table 7) since different types of vegetation require different precipitation and temperature levels and have different tolerances to extreme heat and cold. The significance of these climate variables (annual mean temperature, temperature range, and annual precipitation) has been validated in other studies (Prasad, Iverson \& Liaw, 2006; Sesnie et al., 2008). We looked at two surface albedo indices (the summer surface albedo of band 1 and the winter surface albedo of band 6). Sesnie et al. (2010) combined 
399

400

401

402

403

404

405

406

407

408

409

410

411

412

413

414

415

416

417

418

419

420

421

422

423

424

425

426

427

428

429

430

431

432

433

434

435

436

437

438

elevation and spectral band data to increase the classification accuracy to a satisfactory level for most forest types. De Colstoun et al. (2003) obtained high accuracies (80\%) when classifying coniferous, temperate broad-leaf, and mixed forest types using Landsat ETM+ bands. Other studies have used different vegetation index variables (Price, Guo \& Stiles, 2002; Zhou et al., 2016) specific to their study areas and data.

The input variables used in our vegetation distribution model are not exhaustive. Ecophysiologically meaningful predictors such as soil moisture, $\mathrm{pH}$, and nutrients, should be considered. Other factors, such as actual light, disturbance, biotic interactions, land use, and bioclimatic information could also be incorporated into vegetation distribution models (Dobrowski et al., 2008; Mod et al., 2016; Prasad, Iverson, \& Liaw, 2006; Sesnie et al., 2010). We suggest building more ecophysiologically sound vegetation distribution models that require a collaborative effort across the ecological, geographical, and environmental sciences (Mod et al., 2016).

\section{Other factors affecting classification accuracy}

In addition to classification units, models, and input variables, classification accuracy is affected by other factors, including algorithm error and image data (Li et al., 2014). We must acknowledge the existence of errors in random sample selection, modeling, and data preprocessing algorithms. Remote sensing data sources, as well as the date and processing of selected images, vary, resulting in different simulated values and accuracies (Price, Guo, \& Stiles, 2002). Remote sensing images with high spectral and spatial resolutions provide rich spectral and ground information, moderately improving the predictive ability of the vegetation distribution model (Peng et al., 2002). However, the use of high spectral and spatial resolution images creates a greater demand for data access, larger computer storage capacities, and faster data processors (Price, Guo, \& Stiles, 2002), which is why we did not use high spectral and spatial resolution images in this study. Moreover, some cultivated vegetation and shelter forests in the Jing-Jin-Ji region are greatly affected by human disturbance, which affects their water-heat conditions and soil nutrition. Urbanization reduces vegetation, transforming some areas into industrial, commercial, and residential land. This has led to the direct or indirect pollution of the water, soil, and air, and the reduced predictive ability of vegetation distribution models. The VMC we used for model assessment was published in 2007, and no updated study has been published over the past 10 years. The current state of the Jing-Jin-Ji region's vegetation no longer coincides with the VMC's assessment.

\section{Conclusions}

Our main objective was to determine the best simulation method for vegetation affected by high socioeconomic disturbance in the Jing-Jin-Ji region. The RF model was the most capable at simulating vegetation distribution across all three units. The DT model could simulate the vegetation distribution in units I and II. The SVM and MLC models could not simulate the distribution in any of the three units. Based on the Kappa coefficient, the RF model was

Peer) reviewing PDF | (2020:01:44790:2:0:NEW 5 Aug 2020) 
439

440

441

442

443

444

445

446

447

448

449

450

451

452

453

454

455

456

457

458

459

460

461

462

463

464

465

466

467

468

469

470

471

472

473

474

475

476

477

generally better than the DT model and the most suitable model for simulating vegetation distribution in the Jing-Jin-Ji region. The most important variables affecting vegetation classification accuracy were three climate variables (annual mean temperature, mean diurnal range, and annual precipitation), one geospatial variable (slope), and two spectral variables (Midinfrared ratio of winter vegetation index and brightness index of summer vegetation index). We recommend using the RF model to produce or improve the vegetation maps in areas of high human disturbance.

\section{Acknowledgements}

We thank two anonymous reviewers and the editor for their effort to review this manuscript.

\section{References}

Bannari A, Morin D, Bonn F. 1995. A review of vegetation indices. Remote Sensing Reviews 13(1-2):95-120 DOI:10.1080/02757259509532298.

Bie SW, Beckett PHT. 1973. Comparison of four independent soil surveys by air-photo interpretation, paphos area (cyprus). Photogrammetria 29(6):189-202 DOI:10.1016/00318663(73)90001-x.

Burai P, Deak B, Valko O, Tomor T. 2015. Classification of Herbaceous Vegetation Using Airborne Hyperspectral Imagery. Remote Sensing 7(2):2046-2066 DOI:10.3390/rs70202046.

Box EO. 1981. Macroclimate and plant forms: An introduction to predictive modeling in phytogeography (Tasks for vegetation science 1). London: DR. W. Junk Publishers.

Box EO. 1996. Plant functional types and climate at the global scale. Journal of vegetation science 7(3):309-320 DOI:10.2307/3236274.

Boyd DS, Sanchez-Hernandez C, Foody GM. 2006. Mapping a specific class for priority habitats monitoring from satellite sensor data. International Journal of Remote Sensing 27(13):26312644 DOI:10.1080/01431160600554348.

Chala D, Zimmermann NE, Brochmann C, Bakkestuen V. 2017. Migration corridors for alpine plants among the 'sky islands' of eastern Africa: do they, or did they exist? Alpine Botany 127:133-144 DOI:10.1007/s00035-017-0184-z.

Chen LY, Li H, Zhang PJ, Zhao X, Zhou LH, Liu TY, Hu HF, Bai YF, Shen HH, Fang JY. 2015. Climate and native grassland vegetation as drivers of the community structures of shrubencroached grasslands in Inner Mongolia, China. Landscape Ecology 30(9):1627-1641 DOI:10.1007/s10980-014-0044-9.

Cohen WB, Goward SN. 2004. Landsat's role in ecological applications of remote sensing. Bioscience 54(6):535-545 DOI:10.1641/0006-3568(2004)054[0535:1rieao]2.0.co;2.

Cutler DR, Edwards TC, Beard KH, Cutler A, Hess KT, Gibson J, Lawler JJ. 2007. Random Forests for Classification in Ecology. Ecology 88(11):2783-2792 DOI:10.1890/07-0539.1.

Deng SB. 2010. ENVI remote sensing image processing method. Beijing: Science press. 
478 de Colstoun ECB, Story MH, Thompson C, Commisso K, Smith TG, Irons JR. 2003. National 479 Park vegetation mapping using multitemporal Landsat 7 data and a decision tree classifier.

480 Remote Sensing of Environment 85(3):316-327 DOI:10.1016/s0034-4257(03)00010-5.

481 Dilts TE, Weisberg PJ, Dencker CM, Chambers JC. 2015. Functionally relevant climate

482

483

484

485

486

487

488

489

490

491

492

493

494

495

496

497

498

499

500

501

502

503

504

505

506

507

508

509

510

511

512

513

514

515

516

517 variables for arid lands: a climatic water deficit approach for modelling desert shrub distributions. Journal of Biogeography 42(10):1986-1997 DOI:10.1111/jbi.12561.

Dobrowski SZ, Safford HD, Cheng YB, Ustin SL. 2008. Mapping mountain vegetation using species distribution modeling, image-based texture analysis, and object-based classification. Applied Vegetation Science 11(4):499-508 DOI:10.3170/2008-7-18560.

Dormann CF, Woodin SJ. 2002. Climate change in the Arctic: using plant functional types in a meta-analysis of field experiments. Functional Ecology 16(1):4-17 DOI:10.1046/j.02698463.2001.00596.x.

Editorial Committee of Vegetation Map of China, the Chinese Academy of Sciences. 2007. The Vegetation Map of the People's Republic of China (1:1 000 000). Beijing: Geological Publishing House.

Faber-Langendoen D, Keeler-Wolf T, Meidinger D, Tart D, Hoagland B, Josse C, Navarro G, Ponomarenko S, Saucier J-P, Weakley A, Comer P. 2014. EcoVeg: a new approach to vegetation description and classification. Ecological Monographs 84(4):533-561

DOI:10.1890/13-2334.1.

Fick SE, Hijmans RJ. 2017. WorldClim 2: new 1-km spatial resolution climate surfaces for global land areas. International Journal of Climatology 37(12):4302-4315 DOI:10.1002/joc.5086.

Franklin J. 1995. Predictive vegetation mapping: Geographic modelling of biospatial patterns in relation to environmental gradients. Progress in Physical Geography 19(4):474-499 DOI:10.1177/030913339501900403.

Franklin J. 2010. Mapping species distributions: spatial inference and prediction. Cambridge: Cambridge University Press.

Gislason PO, Benediktsson JA, Sveinsson JR. 2006. Random Forests for land cover classification. Pattern Recognition Letters 27(4):294-300

DOI:10.1016/j.patrec.2005.08.011.

Gunton RM, Polce C, Kunin WE. 2015. Predicting ground temperatures across European landscapes. Methods in Ecology and Evolution 6(5):532-542 DOI:10.1111/2041210x.12355.

Guisan A, Zimmermann NE. 2000. Predictive habitat distribution models in ecology. Ecological modelling 135:147-186 DOI:10.1016/s0304-3800(00)00354-9.

Haslem A, Callister KE, Avitabile SC, Griffioen PA, Kelly LT, Nimmo DG, Spence-Bailey LM, Taylor RS, Watson SJ, Brown L, Bennett AF, Clarke MF. 2010. A framework for mapping vegetation over broad spatial extents: A technique to aid land management across jurisdictional boundaries. Landscape and Urban Planning 97(4):296-305 DOI:10.1016/j.landurbplan.2010.07.002.

Peer) reviewing PDF | (2020:01:44790:2:0:NEW 5 Aug 2020) 
518 Hastie T, Tibshirani R, Friedman J. 2009. The elements of statistical learning: Data Mining, 519 Inference, and Prediction (Second Edition). Berlin: Springer.

520 Hansen MC, Potapov PV, Moore R, Hancher M, Turubanova SA, Tyukavina A, Thau D,

521

522

523

524

525

526

527

528

529

530

531

532

533

534

535

536

537

538

539

540

541

542

543

544

545

546

547

548

549

550

551

552

553

554

555

556 Stehman SV, Goetz SJ, Loveland TR, Kommareddy A, Egorov A, Chini L, Justice CO, Townshend JRG. 2013. High-Resolution Global Maps of 21st-Century Forest Cover Change. Science 342(6160):850-853 DOI:10.1126/science.1244693.

Jakimow B, Oldenburg C, Rabe A, Waske B, Van der Linden S, Hostert P. 2014. ImageRF, Manual for Application: imager (1.1). Available at file:///C:/job\%20software/EnMAPBox_vm/EnMAP-Box/enmapProject/applications/imageRF/help/imageRF_Manual.pdf

Jarnevich CS, Stohlgren TJ, Kumar S, Morisette JT, Holcombe TR. 2015. Caveats for correlative species distribution modeling. Ecological Informatics 29(6-15) DOI:10.1016/j.ecoinf.2015.06.007.

Jiang H, Zhao D, Cai Y, An S. 2012. A Method for Application of Classification Tree Models to Map Aquatic Vegetation Using Remotely Sensed Images from Different Sensors and Dates. Sensors 12(9):12437-12454 DOI:10.3390/s120912437.

Kabacoff RI. 2016. R in action: data analysis and graphics with R (Second Edition). Beijing: Posts \& Telecom Press.

Landis JR, Koch GG. 1977. The Measurement of observer agreement for categorical data. Biometrics 33(1):159-174 DOI:10.2307/2529310.

Langford ZL, Kumar J, Hoffman FM, Breen AL, Iversen CM. 2019. Arctic Vegetation Mapping Using Unsupervised Training Datasets and Convolutional Neural Networks. Remote Sensing 11(1):69 DOI:10.3390/rs11010069.

Lany NK, Zarnetske PL, Finley AO, McCullough DG. 2019. Complementary strengths of spatially-explicit and multi-species distribution models. Ecography 42:1-11 DOI:10.1111/ecog.04728.

Li C, Wang J, Wang L, Hu L, Gong P. 2014. Comparison of Classification Algorithms and Training Sample Sizes in Urban Land Classification with Landsat Thematic Mapper Imagery. Remote Sensing 6(2):964-983 DOI:10.3390/rs6020964.

Lin H, Yue C, WU X, XU H, Zheng X. 2014. Remote sense images classification by Enmap-Box model. Journal of southwest forestry university 2(34):67-71 DOI: 10.3969/j.issn.20951914.2014.02.013 (In Chinese with English abstract).

Ma HJ, Gao XH, Gu XT. 2019. Random forest classification of Landsat 8 imagery for the complex terrain area based on the combination of spectral, topographic and texture information. Journal of Geo-information Science 21(3):359-371 DOI:10.12082/dpxxkx.2019.180346.

Muchoney D, Borak J, Chi H, Friedl M, Gopal S, Hodges J, Morrow N, Strahler A. 2000. Application of the MODIS global supervised classification model to vegetation and land cover mapping of Central America. International Journal of Remote Sensing 21(6-7):11151138 DOI:10.1080/014311600210100. 
557

558

559

560

561

562

563

564

565

566

567

568

569

570

571

572

573

574

575

576

577

578

579

580

581

582

583

584

585

586

587

588

589

590

591

592

593

594

595

596

Mod HK, Scherrer D, Luoto M, Guisan A. 2016. What we use is not what we know: environmental predictors in plant distribution models. Journal of Vegetation Science 27(6):1308-1322 DOI:10.1111/jvs.12444.

Newell CL, Leathwick JR. 2005. Mapping Hurunui forest community distribution, using computer models (Science for Conservation. 251). Wellington: Department of Conservation.

Oke OA, Thompson KA. 2015. Distribution models for mountain plant species: The value of elevation. Ecological Modelling 301:72-77 DOI:10.1016/j.ecolmodel.2015.01.019.

Pal M, Mather PM. 2005. Support vector machines for classification in remote sensing. International Journal of Remote Sensing 26(5):1007-1011 DOI:10.1080/01431160512331314083.

Peng WL, Bai ZP, Liu XN, Cao T. 2002. Introduction to remote sensing. Beijing: Higher education press.

Pfeffer K, Pebesma EJ, Burrough PA. 2003. Mapping alpine vegetation using vegetation observations and topographic attributes. Landscape Ecology 18(8):759-776 DOI:10.1023/B:LAND.0000014471.78787.d0.

Price KP, Guo XL, Stiles JM. 2002. Optimal Landsat TM band combinations and vegetation indices for discrimination of six grassland types in eastern Kansas. International Journal of Remote Sensing 23(23):5031-5042 DOI:10.1080/01431160210121764.

Prasad AM, Iverson LR, Liaw A. 2006. Newer classification and regression tree techniques: Bagging and random forests for ecological prediction. Ecosystems 9(2):181-199 DOI:10.1007/s10021-005-0054-1.

Held M, Rabe A, Jakimow B, van der Linden S, Hostert P. 2014. EnMAP-Box Manual, Version 2.0, Humboldt-Universität zu Berlin, Germany.

Sanchez-Hernandez C, Boyd DS, Foody GM. 2007. Mapping specific habitats from remotely sensed imagery: Support vector machine and support vector data description based classification of coastal saltmarsh habitats. Ecological Informatics 2(2):83-88 DOI:10.1016/j.ecoinf.2007.04.003.

Sesnie SE, Finegan B, Gessler PE, Thessler S, Bendana ZR, Smith AMS. 2010. The multispectral separability of Costa Rican rainforest types with support vector machines and Random Forest decision trees. International Journal of Remote Sensing 31(11):2885-2909 DOI:10.1080/01431160903140803.

Sesnie SE, Gessler PE, Finegan B, Thessler S. 2008. Integrating Landsat TM and SRTM-DEM derived variables with decision trees for habitat classification and change detection in complex neotropical environments. Remote Sensing of Environment 112(5):2145-2159 DOI:10.1016/j.rse.2007.08.025.

Sitch S, Smith B, Prentice IC, Arneth A, Bondeau A, Cramer W, Kaplan JO, Levis S, Lucht W, Sykes MT, Thonicke K, Venevsky S. 2003. Evaluation of ecosystem dynamics, plant geography and terrestrial carbon cycling in the LPJ dynamic global vegetation model. Global Change Biology 9(2):161-185 DOI:10.1046/j.1365-2486.2003.00569.x. 
597 Song MH, Zhou CP, Ouyang H. 2005. Simulated distribution of vegetation types in response to

598

599

600

601

602

603

604

605

606

607

608

609

610

611

612

613

614

615

616

617

618

619

620

621

622

623

624

625

626

627

628

629

630

631

632

633

634

635

636 climate change on the Tibetan Plateau. Journal of Vegetation Science 16(3):341-350 DOI:10.1111/j.1654-1103.2005.tb02372.x.

van der Linden S, Rabe A, Held M, Jakimow B, Leitao PJ, Okujeni A, Schwieder M, Suess S, Hostert P. 2015. The EnMAP-Box-A Toolbox and Application Programming Interface for EnMAP Data Processing. Remote Sensing 7(9):11249-11266 DOI:10.3390/rs70911249.

van der Linden S, Rabe A, Held M, Wirth F, Suess S, Okujeni A, Hostert P. 2014. ImageSVM Classification, Manual for Application: imageSVM version 3.0. Humboldt-Universität zu Berlin, Germany.

Wang L, Gong BL. 2018. Collaborative Governance of Ecological Space in Beijing-TianjinHebei Region. Journal of Tianjin administration institute 20(5):38-44 DOI:10.16326/j.cnki.1008-7168.2018.05.005. (Chinese)

Wang X, Liu G, Coscieme L, Giannetti BF, Hao Y, Zhang Y, Brown MT. 2019. Study on the emergy-based thermodynamic geography of the Jing-Jin-Ji region: Combined multivariate statistical data with DMSP-OLS nighttime lights data. Ecological Modelling 397:1-15 DOI:10.1016/j.ecolmodel.2019.01.021.

Wehkamp J, Pietsch SA, Fuss S, Gusti M, Reuter WH, Koch N, Kindermann G, Kraxner F. 2018. Accounting for institutional quality in global forest modeling. Environmental Modelling \& Software 102:250-259 DOI:10.1016/j.envsoft.2018.01.020.

Weng ES, Zhou GS. 2006. Modeling distribution changes of vegetation in China under future climate change. Environmental Modeling \& Assessment 11(1):45-58 DOI:10.1007/s10666005-9019-1.

Wu YW, Wang NL, Li Z, Chen AA, Guo ZM, Qie YF. 2019. The effect of thermal radiation from surrounding terrain on glacier surface temperatures retrieved from remote sensing data: A case study from Qiyi Glacier, China. Remote Sensing of Environment 231:1-9 DOI: 10.1016/j.rse.2019.111267.

Xie YC, Sha ZY, Yu M. 2008. Remote sensing imagery in vegetation mapping: a review. Journal of Plant Ecology 1(1):9-23 DOI:10.1093/jpe/rtm005.

Zhang G, Biradar CM, Xiao X, Dong J, Zhou Y, Qin Y, Zhang Y, Liu F, Ding M, Thomas RJ. 2018. Exacerbated grassland degradation and desertification in Central Asia during 20002014. Ecological Applications 28(2):442-456 DOI:10.1002/eap.1660.

Zhang WT, Dong W. 2017. SPSS statistical analysis advanced tutorial (Third Edition). Beijing: Higher education press.

Zhang Z, De Clercq E, Ou XK, De Wulf R, Verbeke L. 2008. Mapping dominant vegetation communities at Meili Snow Mountain, Yunnan Province, China using satellite imagery and plant community data. Geocarto International 23(2):135-153

DOI:10.1080/10106040701337410.

Zhao MS, Neilson RP, Yan XD, Dong WJ. 2002. Modelling the vegetation of China under changing climate. Acta geographica sinica 57(1):28-38. DOI:CNKI:SUN:DLXB.0.2002-01003. (Chinese) 
637 Zhao X, Su Y, Hu T, Chen L, Gao S, Wang R, Jin S, Guo Q. 2018. A global corrected SRTM

638 DEM product for vegetated areas. Remote Sensing Letters 9(4):393-402

639 DOI:10.1080/2150704x.2018.1425560.

640 Zheng Y, Xie Z, Jiang L, Shimizu H, Drake S. 2006. Changes in Holdridge Life Zone diversity

641 in the Xinjiang Uygur Autonomous Region (XUAR) of China over the past 40 years.

642 Journal of Arid Environments 66(1):113-126. DOI:10.1016/j.jaridenv.2005.09.005.

643 Zhou J, Lai L, Guan T, Cai W, Gao N, Zhang X, Yang D, Cong Z, Zheng Y. 2016. Comparison

644 modeling for alpine vegetation distribution in an arid area. Environmental Monitoring and

645 Assessment 188(7):408 DOI:10.1007/s10661-016-5417-x. 


\section{Table 1 (on next page)}

Classification units of the vegetation of China 
1 Table 1: Classification units of the vegetation of China

\begin{tabular}{|c|c|c|}
\hline \multicolumn{2}{|c|}{$\begin{array}{l}\text { Vegetation groups (I) Vegetation types } \\
\text { (II) }\end{array}$} & \multirow{2}{*}{$\begin{array}{l}\text { Formations and sub-formations (III) } \\
0 \text { No vegetation }\end{array}$} \\
\hline 0 . No vegetation & 0 No vegetation & \\
\hline 1. Needleleaf forest & $\begin{array}{l}1 \text { Temperate } \\
\text { needleleaf forest }\end{array}$ & 1 Pinus tabulaeformis forest \\
\hline 2. Broadleaf forest & $\begin{array}{l}2 \text { Temperate } \\
\text { broadleaf } \\
\text { deciduous forest }\end{array}$ & $\begin{array}{l}2 \text { Quercus mongolica forest } \\
3 \text { Quercus liaotungensis forest } \\
4 \text { Quercus variabilis forest } \\
5 \text { Robinia pseudoacacia forest } \\
6 \text { Salix matsudana forest } \\
7 \text { Populus davidiana forest } \\
8 \text { Betula platyphylla forest }\end{array}$ \\
\hline 3. Scrub & $\begin{array}{l}3 \text { Temperate } \\
\text { broadleaf } \\
\text { deciduous scrub }\end{array}$ & $\begin{array}{l}9 \text { Corylus heterophylla scrub } \\
10 \text { Lespedeza bicolor scrub } \\
11 \text { Prunus armeniaca var. ansa scrub } \\
12 \text { Vitex negundo var. heterophylla, Zizyphus jujuba } \\
\text { var. spinosa scrub } \\
13 \text { Cotinus coggygria var. cinerea scrub } \\
14 \text { Spiraea spp. scrub } \\
15 \text { Ostryopsis davidiana scrub }\end{array}$ \\
\hline 4. Steppe & $\begin{array}{l}4 \text { Temperate grass- } \\
\text { forb meadow } \\
\text { steppe } \\
5 \text { Temperate } \\
\text { needlegrass arid } \\
\text { steppe }\end{array}$ & $\begin{array}{l}16 \text { Stipa baicalensis, forb meadow steppe } \\
17 \text { Filifolium sibiricum, grass-forb meadow steppe } \\
18 \text { Aneurolepidium chinense, needlegrass steppe } \\
19 \text { Stipa krylovii steppe } \\
20 \text { Stipa bungiana steppe } \\
21 \text { Thymus mongolicus, needlegrass steppe }\end{array}$ \\
\hline $\begin{array}{l}\text { 5. Grass-forb } \\
\text { community }\end{array}$ & $\begin{array}{l}6 \text { Temperate grass- } \\
\text { forb community }\end{array}$ & $\begin{array}{l}22 \text { Bothriochloa ischaemum community } \\
23 \text { Bothriochloa ischaemum community } \\
24 \text { Vitex negundo var. heterophylla, Zizyphus jujuba } \\
\text { var. spinosus, Bothriochloa ischaemum scrub and } \\
\text { grass community } \\
25 \text { Vitex negundo var. heterophylla, Zizyphus jujuba } \\
\text { var. spinosus, Themeda triandra var. japonica scrub } \\
\text { and grass community }\end{array}$ \\
\hline 6. Meadow & $\begin{array}{l}7 \text { Temperate grass } \\
\text { and forb } \\
\text { meadow }\end{array}$ & $\begin{array}{l}26 \text { Arundinella hirta, Spodiopogon sibiricus, forb } \\
\text { meadow }\end{array}$ \\
\hline & $\begin{array}{l}8 \text { Temperate grass } \\
\text { and forb } \\
\text { holophytic } \\
\text { meadow }\end{array}$ & $\begin{array}{l}27 \text { Carex spp., forb meadow } \\
28 \text { Achnatherum splendens holophytic meadow } \\
29 \text { Suaeda glauca holophytic meadow }\end{array}$ \\
\hline 7. Swamp & $\begin{array}{l}9 \text { Cold-temperate } \\
\text { and temperate } \\
\text { swamp }\end{array}$ & 30 Phragmites communis swamp \\
\hline
\end{tabular}


8. Cultural vegetation
10 One crop annually and cold-resistant economic crops

11 One crop
annually, coldresistant economic crops and deciduous orchards

12 Three crops two 33 Winter wheat, coarse grains years and two crops annually non irrigation, deciduous orchards

32 Coarse grains

34 Coarse grains

35 Rice

36 Winter wheat, corn, cotton

37 Apple, pear orchard
31 Spring wheat, naked oats, buckwheat, potatoes; flux

38 Winter wheat, corn, Chinese sorghum, sweet potatoes; cotton, tabacco, peanut, sesame; apple, pear, hauthorn, persimmon, walnut, pomegranat, grape

39 Winter wheat, coarse grains (loamy soil)

2

3

4 
Table 2 (on next page)

The vegetation indices 
1 Table 2: The vegetation indices

\begin{tabular}{|c|c|c|}
\hline Indices & Abbreviation & Formula \\
\hline Ratio vegetation index & RVI & NIR/Red \\
\hline Brightness index & $\mathrm{BI}$ & $\begin{array}{l}0.2909 \mathrm{Blue}+0.2493 \mathrm{Green}+0.4806 \mathrm{Red}+ \\
0.5568 \mathrm{NIR}+0.4438 \mathrm{SWIR} 1+0.1706 \mathrm{SWIR} 2\end{array}$ \\
\hline Green vegetation index & GI & $\begin{array}{l}-0.2728 \text { Blue }-0.2174 \text { Green-0.5508Red }+ \\
0.7221 \text { NIR }+0.0733 \text { SWIR } 1-0.1648 \text { SWIR2 }\end{array}$ \\
\hline Wetness index & WI & $\begin{array}{l}0.1446 \text { Blue }+0.1761 \text { Green }+0.3322 \text { Red }+ \\
0.3396 \text { NIR }-0.6210 \text { SWIR } 1-0.4186 \text { SWIR2 }\end{array}$ \\
\hline Differenced vegetation index & DVI & NIR - Red \\
\hline Green ratio & GR & NIR/Green \\
\hline Mid-infrared ratio & MR & NIR/SWIR1 \\
\hline Soil-adjusted vegetation index & SAVI & $(1.5(\mathrm{NIR}-\mathrm{Red})) /((\mathrm{NIR}+\mathrm{Red}+0.5))$ \\
\hline $\begin{array}{l}\text { Optimization of soil-adjusted } \\
\text { vegetation index }\end{array}$ & OSAVI & $(1.16(\mathrm{NIR}-\mathrm{Red})) /((\mathrm{NIR}+\mathrm{Red}+0.16))$ \\
\hline $\begin{array}{l}\text { Atmospherically resistant vegetation } \\
\text { index }\end{array}$ & ARVI & $(\mathrm{NIR}-(2 * \operatorname{Red}-\mathrm{Blue})) /(\mathrm{NIR}+(2 *$ Red - Blue $))$ \\
\hline Normalized difference vegetation index & NDVI & $(\mathrm{NIR}-\mathrm{Red}) /(\mathrm{NIR}+\mathrm{Red})$ \\
\hline Enhanced vegetation index & EVI & $2.5[(\mathrm{NIR}-\mathrm{Red}) /(\mathrm{NIR}+6 *$ Red $-7.5 \mathrm{Blue}+1)]$ \\
\hline Normalized difference tillage index & NDTI & $($ SWIR1-SWIR2)/(SWIR1 + SWIR2) \\
\hline $\begin{array}{l}\text { Normalized difference senescent } \\
\text { vegetation index }\end{array}$ & NDSVI & $($ SWIR1-Red)/(SWIR1 + Red) \\
\hline
\end{tabular}




\section{Table 3(on next page)}

Variable combinations

Note: DT10 and RF10 represent the top 10 important variables of decision tree (DT) and random forest (RF) methods with combination 9 in the vegetation group level, respectively. The vegetation indices and their abbreviations were shown in Table 2. 


\section{Table 3: Variable combinations.}

2 DT10 and RF10 represent the top 10 important variables of decision tree (DT) and random forest

3 (RF) methods with combination 9 in the vegetation group level, respectively. The vegetation

4 indices and their abbreviations were shown in Table 2.

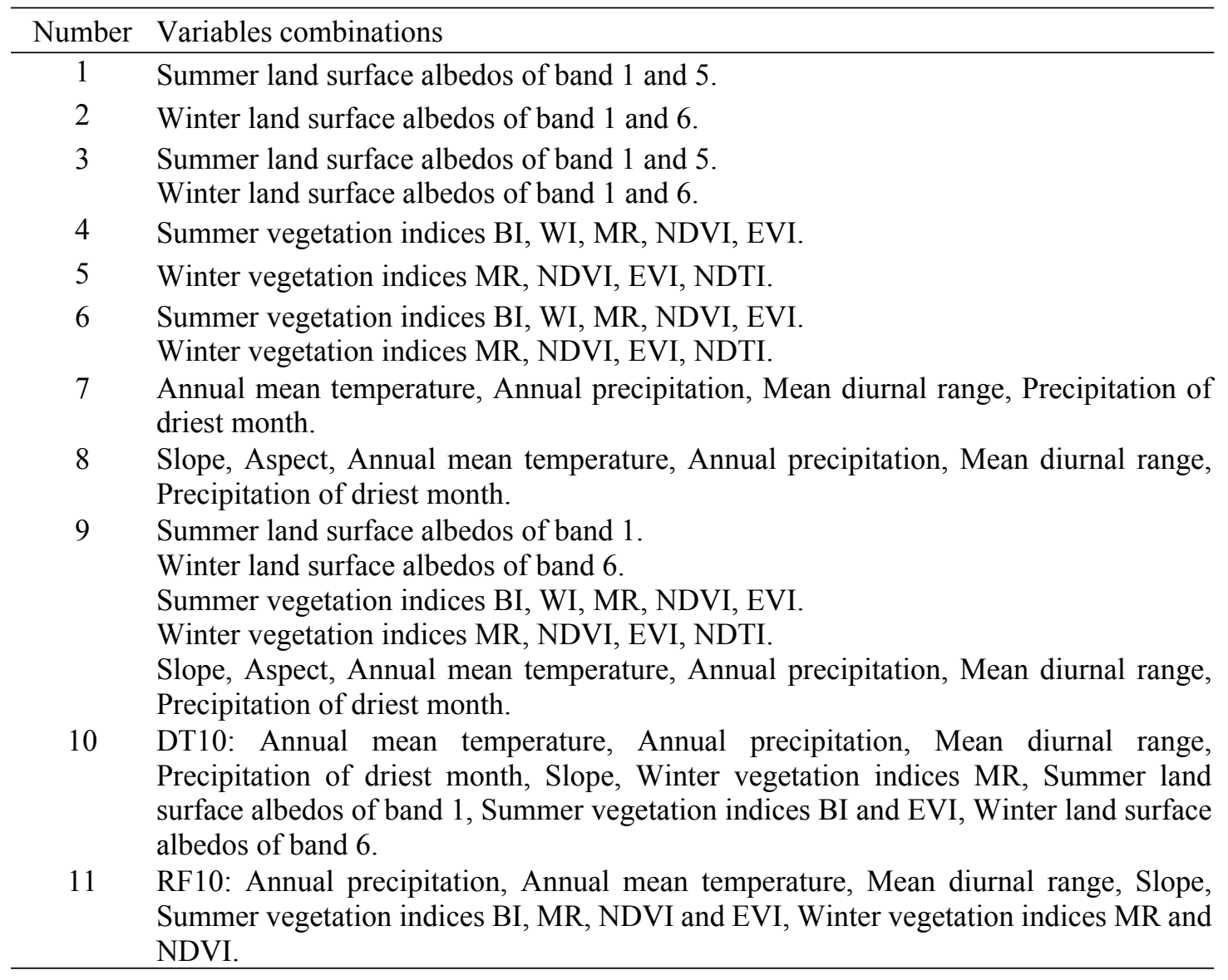




\section{Table 4(on next page)}

Model assessment of vegetation groups by field point data and VMC.

Variable combinations were shown in Table 3. VMC, the Vegetation Map of the People's

Republic of China. **, the kappa coefficient lager than 0.56 ; *, the kappa coefficient larger than 0.4 and less than 0.56. OA, Overall accuracy; KC, Kappa coefficient. 
1 Table 4: Model assessment of vegetation groups by field point data and VMC.

2 Variable combinations were shown in Table 3. VMC, the Vegetation Map of the People's Republic of China. **, the kappa coefficient

3 lager than 0.56 ; *, the kappa coefficient larger than 0.4 and less than 0.56. OA, Overall accuracy; KC, Kappa coefficient.

\begin{tabular}{|c|c|c|c|c|c|c|c|c|c|c|c|c|c|c|c|c|}
\hline \multirow{3}{*}{$\begin{array}{c}\text { Variable } \\
\text { combinations }\end{array}$} & \multicolumn{4}{|c|}{ Decision tree } & \multicolumn{4}{|c|}{ Random forest } & \multicolumn{4}{|c|}{ Support vector machine } & \multicolumn{4}{|c|}{$\begin{array}{l}\text { Maximum likelihood } \\
\text { classification }\end{array}$} \\
\hline & \multicolumn{2}{|c|}{ Point data } & \multicolumn{2}{|c|}{ VMC } & \multicolumn{2}{|c|}{ Point data } & \multicolumn{2}{|c|}{ VMC } & \multicolumn{2}{|c|}{ Point data } & \multicolumn{2}{|c|}{ VMC } & \multicolumn{2}{|c|}{ Point data } & \multicolumn{2}{|c|}{ VMC } \\
\hline & $\mathrm{OA}$ & $\mathrm{KC}$ & $\mathrm{OA}$ & $\mathrm{KC}$ & $\mathrm{OA}$ & $\mathrm{KC}$ & $\mathrm{OA}$ & $\mathrm{KC}$ & $\mathrm{OA}$ & $\mathrm{KC}$ & $\mathrm{OA}$ & $\mathrm{KC}$ & $\mathrm{OA}$ & $\mathrm{KC}$ & $\mathrm{OA}$ & $\mathrm{KC}$ \\
\hline 1 & $34 \%$ & 0.18 & $55 \%$ & 0.22 & $37 \%$ & 0.24 & $32 \%$ & 0.09 & $36 \%$ & 0.21 & $53 \%$ & 0.21 & $23 \%$ & 0.08 & $11 \%$ & 0.02 \\
\hline 2 & $38 \%$ & 0.20 & $52 \%$ & 0.23 & $39 \%$ & 0.27 & $37 \%$ & 0.13 & $35 \%$ & 0.20 & $55 \%$ & 0.24 & $18 \%$ & 0.07 & $9 \%$ & 0.03 \\
\hline 3 & $45 \%$ & 0.31 & $54 \%$ & 0.26 & $47 \%$ & 0.36 & $45 \%$ & 0.21 & $41 \%$ & 0.27 & $54 \%$ & 0.27 & $24 \%$ & 0.12 & $15 \%$ & 0.05 \\
\hline 4 & $32 \%$ & 0.16 & $46 \%$ & 0.16 & $42 \%$ & 0.30 & $42 \%$ & 0.17 & $37 \%$ & 0.22 & $57 \%$ & 0.26 & $11 \%$ & 0.04 & $3 \%$ & 0.01 \\
\hline 5 & $31 \%$ & 0.11 & $59 \%$ & 0.14 & $44 \%$ & 0.32 & $44 \%$ & 0.19 & $36 \%$ & 0.22 & $51 \%$ & 0.22 & $9 \%$ & 0.04 & $4 \%$ & 0.02 \\
\hline 6 & $41 \%$ & 0.26 & $44 \%$ & 0.18 & $50 \%$ & $0.40 *$ & $52 \%$ & 0.27 & $42 \%$ & 0.29 & $54 \%$ & 0.27 & $13 \%$ & 0.08 & $4 \%$ & 0.03 \\
\hline 7 & $54 \%$ & $0.45^{*}$ & $57 \%$ & 0.34 & $72 \%$ & $0.66^{* *}$ & $55 \%$ & 0.35 & & & & & & & & \\
\hline 8 & $55 \%$ & $0.46^{*}$ & $56 \%$ & 0.35 & $69 \%$ & $0.63^{* *}$ & $56 \%$ & 0.37 & & & & & & & & \\
\hline 9 & $55 \%$ & $0.46^{*}$ & $53 \%$ & 0.34 & $68 \%$ & $0.61^{* *}$ & $57 \%$ & 0.38 & & & & & & & & \\
\hline 10 & $55 \%$ & $0.46^{*}$ & $53 \%$ & 0.33 & $69 \%$ & $0.63^{* *}$ & $57 \%$ & 0.38 & & & & & & & & \\
\hline 11 & $56 \%$ & $0.46^{*}$ & $56 \%$ & 0.36 & $68 \%$ & $0.62 * *$ & $57 \%$ & 0.38 & & & & & & & & \\
\hline
\end{tabular}




\section{Table 5 (on next page)}

Model assessment of vegetation types by field point data and VMC.

The Abbreviations were same with Table 4. 
1 Table 5: Model assessment of vegetation types by field point data and VMC.

2 The Abbreviations were same with Table 4.

\begin{tabular}{|c|c|c|c|c|c|c|c|c|c|c|c|c|c|c|c|c|}
\hline \multirow{3}{*}{$\begin{array}{c}\text { Variable } \\
\text { combinations }\end{array}$} & \multicolumn{4}{|c|}{ Decision tree } & \multicolumn{4}{|c|}{ Random forest } & \multicolumn{4}{|c|}{ Support vector machine } & \multicolumn{4}{|c|}{$\begin{array}{c}\text { Maximum likelihood } \\
\text { classification }\end{array}$} \\
\hline & \multicolumn{2}{|c|}{ Point data } & \multicolumn{2}{|c|}{ VMC } & \multicolumn{2}{|c|}{ Point data } & \multicolumn{2}{|c|}{ VMC } & \multicolumn{2}{|c|}{ Point data } & \multicolumn{2}{|c|}{ VMC } & \multicolumn{2}{|c|}{ Point data } & \multicolumn{2}{|c|}{ VMC } \\
\hline & $\mathrm{OA}$ & $\mathrm{KC}$ & $\mathrm{OA}$ & $\mathrm{KC}$ & $\mathrm{OA}$ & $\mathrm{KC}$ & $\mathrm{OA}$ & $\mathrm{KC}$ & $\mathrm{OA}$ & $\mathrm{KC}$ & $\mathrm{OA}$ & $\mathrm{KC}$ & $\mathrm{OA}$ & $\mathrm{KC}$ & $\mathrm{OA}$ & $\mathrm{KC}$ \\
\hline 1 & $42 \%$ & 0.24 & $63 \%$ & 0.33 & $32 \%$ & 0.22 & $23 \%$ & 0.09 & $32 \%$ & 0.18 & $40 \%$ & 0.18 & $6 \%$ & 0.02 & $7 \%$ & 0.00 \\
\hline 2 & $44 \%$ & 0.27 & $58 \%$ & 0.31 & $34 \%$ & 0.23 & $30 \%$ & 0.14 & $31 \%$ & 0.18 & $44 \%$ & 0.24 & $5 \%$ & 0.02 & $14 \%$ & 0.00 \\
\hline 3 & $43 \%$ & 0.30 & $58 \%$ & 0.35 & $44 \%$ & 0.34 & $38 \%$ & 0.22 & $37 \%$ & 0.26 & $43 \%$ & 0.25 & $9 \%$ & 0.05 & $13 \%$ & 0.00 \\
\hline 4 & $36 \%$ & 0.20 & $47 \%$ & 0.20 & $39 \%$ & 0.29 & $31 \%$ & 0.15 & $32 \%$ & 0.19 & $43 \%$ & 0.21 & $13 \%$ & 0.07 & $6 \%$ & 0.02 \\
\hline 5 & $32 \%$ & 0.14 & $59 \%$ & 0.23 & $41 \%$ & 0.31 & $36 \%$ & 0.19 & $34 \%$ & 0.22 & $43 \%$ & 0.22 & $6 \%$ & 0.03 & $6 \%$ & 0.03 \\
\hline 6 & $36 \%$ & 0.23 & $45 \%$ & 0.24 & $47 \%$ & 0.38 & $44 \%$ & 0.27 & $40 \%$ & 0.29 & $43 \%$ & 0.25 & $14 \%$ & 0.09 & $21 \%$ & 0.06 \\
\hline 7 & $55 \%$ & $0.46^{*}$ & $72 \%$ & $0.54 *$ & $70 \%$ & $0.65^{* *}$ & $54 \%$ & $0.41 *$ & & & & & & & & \\
\hline 8 & $53 \%$ & $0.44^{*}$ & $68 \%$ & $0.52 *$ & $68 \%$ & $0.63^{* *}$ & $55 \%$ & $0.43^{*}$ & & & & & & & & \\
\hline 9 & $54 \%$ & $0.45^{*}$ & $65 \%$ & $0.49 *$ & $66 \%$ & $0.60^{* *}$ & $55 \%$ & $0.43 *$ & & & & & & & & \\
\hline 10 & $54 \%$ & $0.45^{*}$ & $65 \%$ & $0.49 *$ & $68 \%$ & $0.63^{* *}$ & $55 \%$ & $0.43^{*}$ & & & & & & & & \\
\hline 11 & $53 \%$ & $0.44^{*}$ & $68 \%$ & $0.52 *$ & $67 \%$ & $0.62^{* *}$ & $55 \%$ & $0.43^{*}$ & & & & & & & & \\
\hline
\end{tabular}

3 


\section{Table 6(on next page)}

Model assessment of formations and subformations by field point data and VMC.

The Abbreviations were same with Table 4. 
1 Table 6: Model assessment of formations and subformations by field point data and VMC.

2 The Abbreviations were same with Table 4.

\begin{tabular}{|c|c|c|c|c|c|c|c|c|c|c|c|c|c|c|c|c|}
\hline \multirow{3}{*}{$\begin{array}{c}\text { Variable } \\
\text { combinations }\end{array}$} & \multicolumn{4}{|c|}{ Decision tree } & \multicolumn{4}{|c|}{ Random forest } & \multicolumn{4}{|c|}{ Support vector machine } & \multicolumn{4}{|c|}{ Maximum likelihood classification } \\
\hline & \multicolumn{2}{|c|}{ Point data } & \multicolumn{2}{|c|}{ VMC } & \multicolumn{2}{|c|}{ Point data } & \multicolumn{2}{|c|}{ VMC } & \multicolumn{2}{|c|}{ Point data } & \multicolumn{2}{|c|}{ VMC } & \multicolumn{2}{|c|}{ Point data } & \multicolumn{2}{|c|}{ VMC } \\
\hline & $\mathrm{OA}$ & $\mathrm{KC}$ & $\mathrm{OA}$ & $\mathrm{KC}$ & $\mathrm{OA}$ & $\mathrm{KC}$ & $\mathrm{OA}$ & $\mathrm{KC}$ & $\mathrm{OA}$ & $\mathrm{KC}$ & $\mathrm{OA}$ & $\mathrm{KC}$ & OA & $\mathrm{KC}$ & $\mathrm{OA}$ & $\mathrm{KC}$ \\
\hline 1 & $23 \%$ & 0.14 & $19 \%$ & 0.08 & $20 \%$ & 0.18 & $5 \%$ & 0.02 & $11 \%$ & 0.09 & $6 \%$ & 0.03 & $8 \%$ & 0.06 & $8 \%$ & 0.04 \\
\hline 2 & $22 \%$ & -0.04 & $49 \%$ & 0.04 & $19 \%$ & 0.17 & $6 \%$ & 0.03 & $13 \%$ & 0.11 & $7 \%$ & 0.04 & $8 \%$ & 0.06 & $13 \%$ & 0.05 \\
\hline 3 & $26 \%$ & 0.14 & $45 \%$ & 0.23 & $29 \%$ & 0.27 & $9 \%$ & 0.07 & $21 \%$ & 0.19 & $10 \%$ & 0.07 & $12 \%$ & 0.09 & $13 \%$ & 0.07 \\
\hline 4 & $30 \%$ & 0.20 & $30 \%$ & 0.04 & $22 \%$ & 0.20 & $7 \%$ & 0.04 & $16 \%$ & 0.14 & $6 \%$ & 0.03 & $9 \%$ & 0.07 & $8 \%$ & 0.04 \\
\hline 7 & $33 \%$ & 0.20 & $52 \%$ & 0.27 & $58 \%$ & $0.57 * *$ & $23 \%$ & 0.20 & & & & & & & & \\
\hline 8 & $27 \%$ & 0.17 & $34 \%$ & 0.18 & $55 \%$ & $0.54 *$ & $23 \%$ & 0.20 & & & & & & & & \\
\hline 9 & $25 \%$ & 0.15 & $22 \%$ & 0.15 & $55 \%$ & $0.53^{*}$ & $22 \%$ & 0.20 & & & & & & & & \\
\hline 10 & $30 \%$ & 0.17 & $41 \%$ & 0.22 & $56 \%$ & $0.55^{*}$ & $23 \%$ & 0.21 & & & & & & & & \\
\hline 11 & $31 \%$ & 0.20 & $41 \%$ & 0.22 & $56 \%$ & $0.55^{*}$ & $23 \%$ & 0.20 & & & & & & & & \\
\hline
\end{tabular}

3 


\section{Table 7 (on next page)}

Top ten most important variables of models in the different vegetation classification units.

The abbreviations of indices were shown in Table 2. 
1 Table 7: Top ten most important variables of models in the different vegetation classification units.

2 The abbreviations of indices were shown in Table 2.

\begin{tabular}{|c|c|c|c|c|c|c|c|c|c|c|c|c|}
\hline \multicolumn{5}{|c|}{ Vegetation groups } & \multicolumn{4}{|c|}{ Vegetation types } & \multicolumn{4}{|c|}{ Formations and sub-formations } \\
\hline & \multicolumn{2}{|l|}{ Decision tree } & \multicolumn{2}{|l|}{ Random forest } & \multicolumn{2}{|l|}{ Decision tree } & \multicolumn{2}{|c|}{ Random forest } & Decision tree & \multicolumn{3}{|c|}{ Random forest } \\
\hline & $\begin{array}{l}\text { Important } \\
\text { variables }\end{array}$ & $\begin{array}{l}\text { Standardized } \\
\text { Importance }\end{array}$ & $\begin{array}{l}\text { Important } \\
\text { variables }\end{array}$ & $\begin{array}{l}\text { Normalized } \\
\text { importance }\end{array}$ & $\begin{array}{l}\text { Important } \\
\text { variables }\end{array}$ & $\begin{array}{l}\text { Standardized } \\
\text { Importance }\end{array}$ & $\begin{array}{l}\text { Important } \\
\text { variables }\end{array}$ & $\begin{array}{l}\text { Normalized } \\
\text { importance }\end{array}$ & $\begin{array}{l}\text { Important } \\
\text { variables }\end{array}$ & $\begin{array}{l}\text { Standardized } \\
\text { Importance }\end{array}$ & $\begin{array}{l}\text { Important } \\
\text { variables }\end{array}$ & $\begin{array}{l}\text { Normalized } \\
\text { importance }\end{array}$ \\
\hline 1 & $\begin{array}{l}\text { Annual mean } \\
\text { temperature }\end{array}$ & n 1.00 & $\begin{array}{l}\text { Annual mean } \\
\text { temperature }\end{array}$ & 3.68 & $\begin{array}{l}\text { Annual mean } \\
\text { temperature }\end{array}$ & $\mathrm{n} 1.00$ & $\begin{array}{l}\text { Annual mear } \\
\text { temperature }\end{array}$ & n3.51 & $\begin{array}{l}\text { Annual mean } \\
\text { temperature }\end{array}$ & 1.00 & $\begin{array}{l}\text { Annual mean } \\
\text { temperature }\end{array}$ & 4.16 \\
\hline 2 & $\begin{array}{l}\text { Annual } \\
\text { precipitation }\end{array}$ & 0.88 & Slope & 2.94 & Slope & 0.83 & Slope & 3.35 & $\begin{array}{l}\text { Annual } \\
\text { precipitation }\end{array}$ & 0.86 & $\begin{array}{l}\text { Annual } \\
\text { precipitation }\end{array}$ & 3.28 \\
\hline 3 & Slope & 0.80 & $\begin{array}{l}\text { Mean diurnal } \\
\text { range }\end{array}$ & 2.60 & $\begin{array}{l}\text { Annual } \\
\text { precipitation }\end{array}$ & 0.51 & $\begin{array}{l}\text { Mean diurna } \\
\text { range }\end{array}$ & 13.06 & Slope & 0.63 & $\begin{array}{l}\text { Mean diurnal } \\
\text { range }\end{array}$ & 3.25 \\
\hline 4 & $\begin{array}{l}\text { Winter } \\
\text { vegetation } \\
\text { index MR }\end{array}$ & 0.36 & $\begin{array}{l}\text { Annual } \\
\text { precipitation }\end{array}$ & 2.38 & $\begin{array}{l}\text { Winter } \\
\text { vegetation } \\
\text { index MR }\end{array}$ & 0.30 & $\begin{array}{l}\text { Annual } \\
\text { precipitation }\end{array}$ & 2.8 & $\begin{array}{l}\text { Mean diurnal } \\
\text { range }\end{array}$ & 0.52 & Slope & 2.24 \\
\hline 5 & $\begin{array}{l}\text { Mean diurnal } \\
\text { range }\end{array}$ & 10.33 & $\begin{array}{l}\text { Summer } \\
\text { vegetation } \\
\text { index BI }\end{array}$ & 1.88 & $\begin{array}{l}\text { Mean diurnal } \\
\text { range }\end{array}$ & 10.28 & $\begin{array}{l}\text { Summer } \\
\text { vegetation } \\
\text { index BI }\end{array}$ & 1.84 & $\begin{array}{l}\text { Precipitation } \\
\text { of driest } \\
\text { month }\end{array}$ & 0.52 & $\begin{array}{l}\text { Precipitation } \\
\text { of driest } \\
\text { month }\end{array}$ & 2.16 \\
\hline 6 & $\begin{array}{l}\text { Summer } \\
\text { surface } \\
\text { albedo of } \\
\text { band } 1\end{array}$ & 0.29 & $\begin{array}{l}\text { Winter } \\
\text { vegetation } \\
\text { index NDVI }\end{array}$ & 1.37 & $\begin{array}{l}\text { Summer } \\
\text { vegetation } \\
\text { index EVI }\end{array}$ & 0.22 & $\begin{array}{l}\text { Winter } \\
\text { vegetation } \\
\text { index NDVI }\end{array}$ & 1.61 & $\begin{array}{l}\text { Winter } \\
\text { vegetation } \\
\text { index MR }\end{array}$ & 0.4 & $\begin{array}{l}\text { Summer } \\
\text { vegetation } \\
\text { index BI }\end{array}$ & 1.83 \\
\hline 7 & $\begin{array}{l}\text { Summer } \\
\text { vegetation } \\
\text { index BI }\end{array}$ & 0.28 & $\begin{array}{l}\text { Summer } \\
\text { vegetation } \\
\text { index EVI }\end{array}$ & 1.36 & $\begin{array}{l}\text { Precipitation } \\
\text { of driest } \\
\text { month }\end{array}$ & 0.21 & $\begin{array}{l}\text { Winter } \\
\text { vegetation } \\
\text { index MR }\end{array}$ & 1.45 & $\begin{array}{l}\text { Summer } \\
\text { surface albedo } \\
\text { of band } 1\end{array}$ & 0.32 & $\begin{array}{l}\text { Summer } \\
\text { vegetation } \\
\text { index NDVI }\end{array}$ & 1.7 \\
\hline 8 & $\begin{array}{l}\text { Precipitation } \\
\text { of driest } \\
\text { month }\end{array}$ & 0.25 & $\begin{array}{l}\text { Winter } \\
\text { vegetation } \\
\text { index MR }\end{array}$ & 1.30 & $\begin{array}{l}\text { Summer } \\
\text { vegetation } \\
\text { index BI }\end{array}$ & 0.20 & $\begin{array}{l}\text { Summer } \\
\text { vegetation } \\
\text { index WI }\end{array}$ & 1.31 & $\begin{array}{l}\text { Summer } \\
\text { vegetation } \\
\text { index BI }\end{array}$ & 0.32 & $\begin{array}{l}\text { Winter } \\
\text { vegetation } \\
\text { index NDVI }\end{array}$ & 1.61 \\
\hline 9 & $\begin{array}{l}\text { Summer } \\
\text { vegetation } \\
\text { index EVI }\end{array}$ & 0.23 & $\begin{array}{l}\text { Summer } \\
\text { vegetation } \\
\text { index NDVI }\end{array}$ & 1.22 & $\begin{array}{l}\text { Summer } \\
\text { surface } \\
\text { albedo of } \\
\text { band } 1\end{array}$ & 0.19 & $\begin{array}{l}\text { Precipitation } \\
\text { of driest } \\
\text { month }\end{array}$ & 1.24 & $\begin{array}{l}\text { Summer } \\
\text { vegetation } \\
\text { index WI }\end{array}$ & 0.31 & $\begin{array}{l}\text { Winter } \\
\text { vegetation } \\
\text { index MR }\end{array}$ & 1.47 \\
\hline & $\begin{array}{l}0 \text { Winter } \\
\text { surface } \\
\text { albedo of }\end{array}$ & 0.19 & $\begin{array}{l}\text { Summer } \\
\text { vegetation } \\
\text { index MR }\end{array}$ & 1.12 & $\begin{array}{l}\text { Winter } \\
\text { surface } \\
\text { albedo of }\end{array}$ & 0.14 & $\begin{array}{l}\text { Summer } \\
\text { vegetation } \\
\text { index NDVI }\end{array}$ & 1.22 & $\begin{array}{l}\text { Winter surface } \\
\text { albedo of band } \\
6\end{array}$ & & $\begin{array}{l}\text { Summer } \\
\text { vegetation } \\
\text { indices EVI }\end{array}$ & 1.32 \\
\hline
\end{tabular}


Figure 1

The location and DEM of the Jing-Jin-Ji region. 


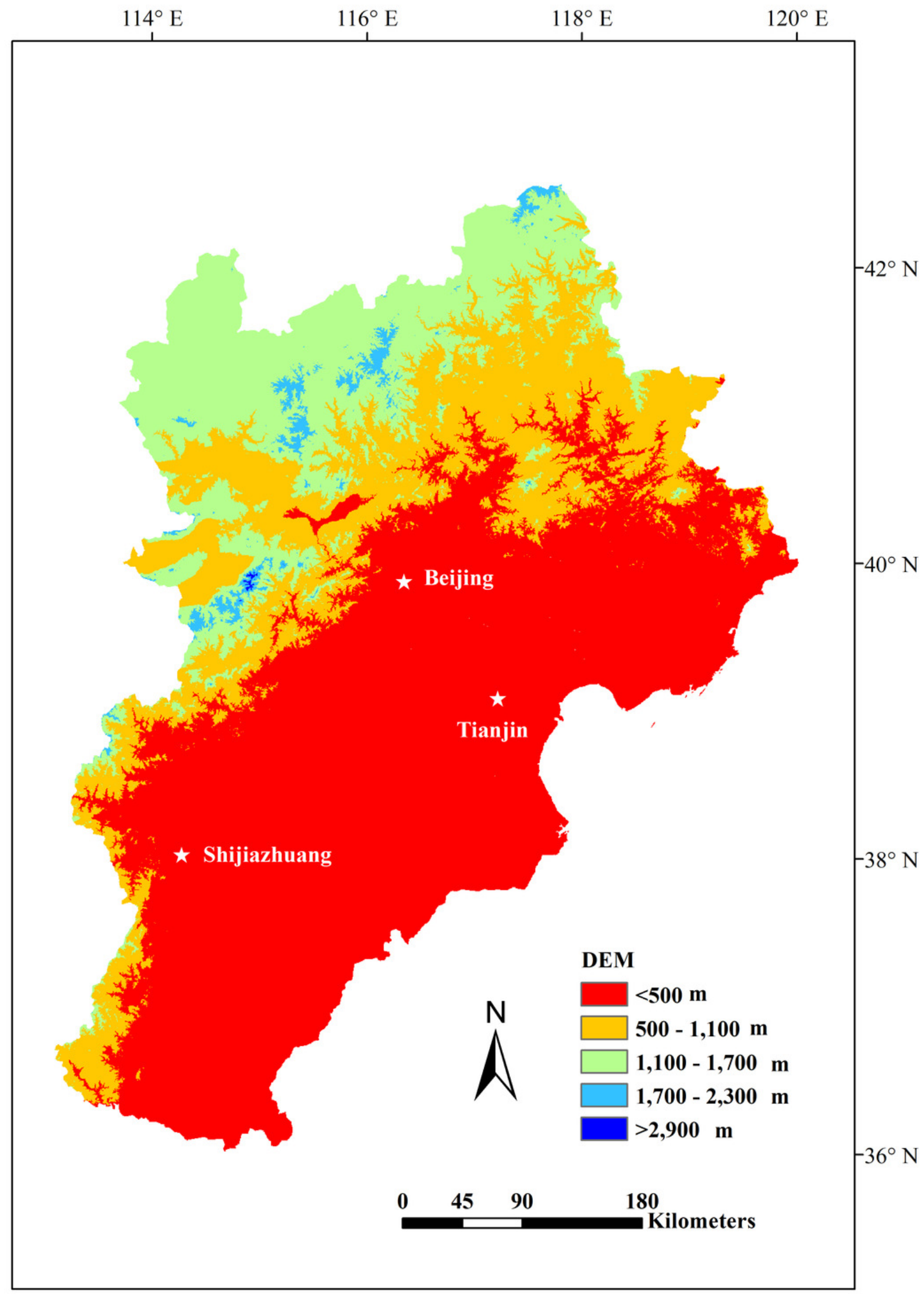




\section{Figure 2}

The modeling vegetation map of vegetation groups with highest accuracy by four methods and the VMC in Jing-Jin-Ji region.

Decision tree model (a), random forest model (b), support vector machine (c), maximum likelihood classification (d), the Vegetation Map of the People's Republic of China (VMC) (e); The legend represents vegetation groups shown in Table 1.

(a)

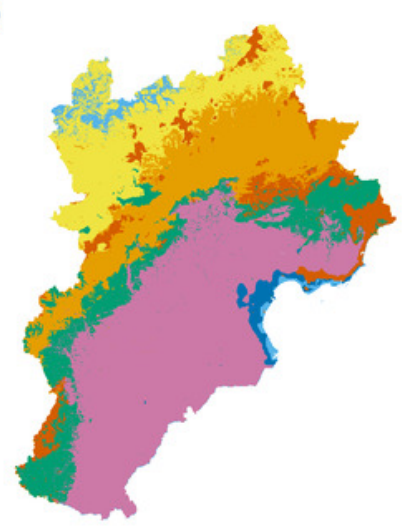

(d)

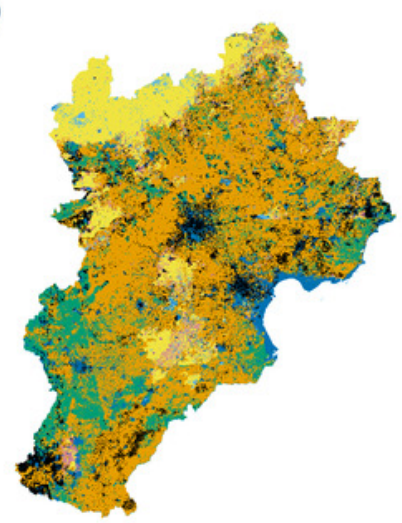

(b)

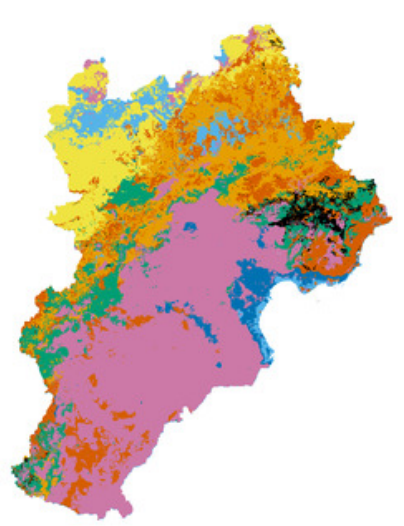

(e)

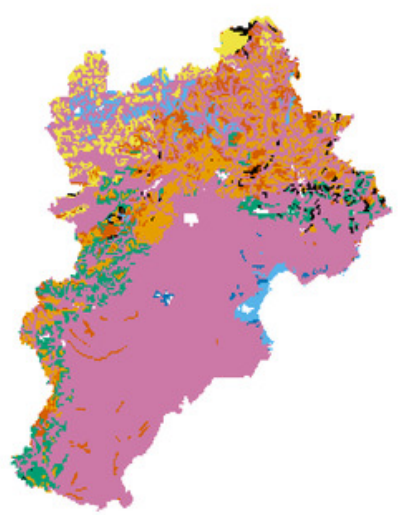

(c)

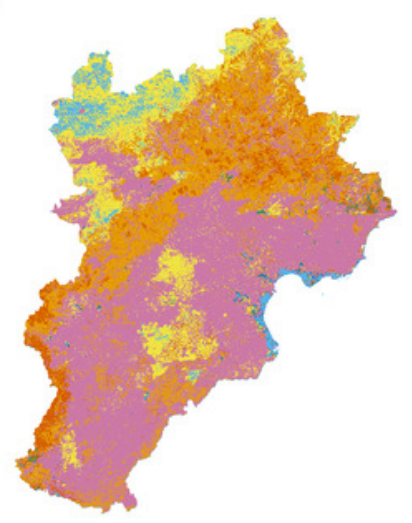

Legend

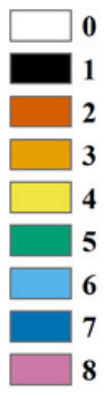

$\Lambda$

Kilometers 


\section{Figure 3}

The modeling vegetation map of vegetation types with highest accuracy by four methods and the VMC in Jing-Jin-Ji region.

Decision tree model (a), random forest model (b), support vector machine (c), maximum likelihood classification (d), the Vegetation Map of the People's Republic of China (VMC) (e); The legend represents vegetation groups shown in Table 1.

(a)

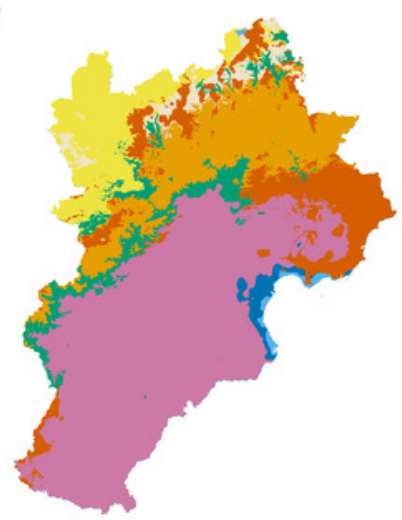

(d)

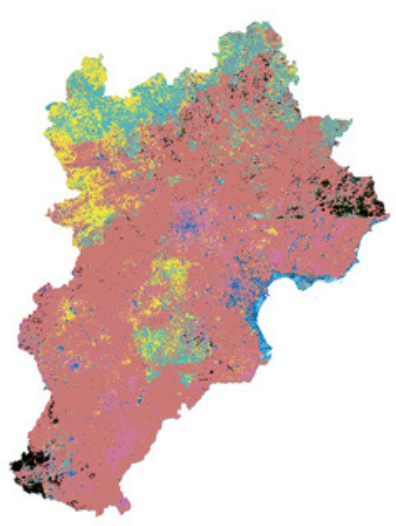

(b)

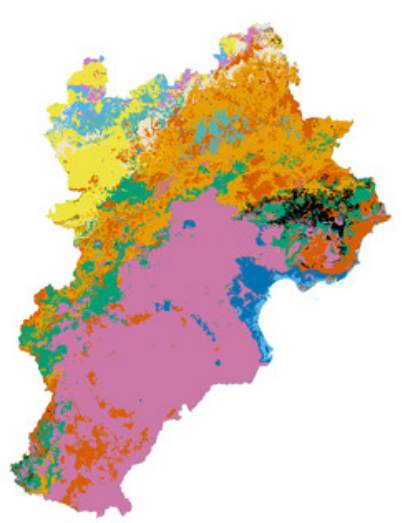

(e)

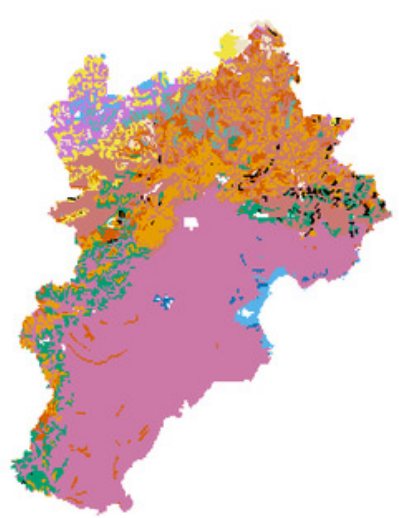

(c)

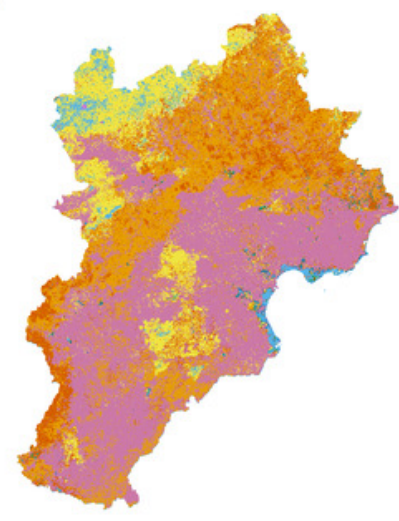

Legend

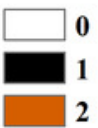

2

3
$\square$
$\square$

$\square 5$

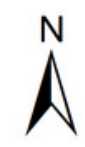

$\begin{array}{r}6 \\ \hline\end{array}$

$\square$

$\mathbf{9}$
$\square \quad 10$

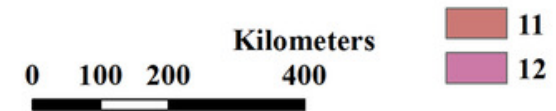




\section{Figure 4}

The modeling vegetation map of formations and sub-formations with highest accuracy by four methods and the VMC in Jing-Jin-Ji region.

Decision tree model (a), random forest model (b), support vector machine (c), maximum likelihood classification (d), the Vegetation Map of the People's Republic of China (VMC) (e); The legend represents vegetation groups shown in Table 1.

(a)

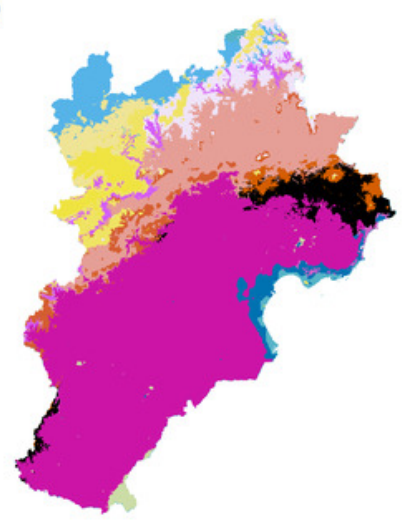

(d)

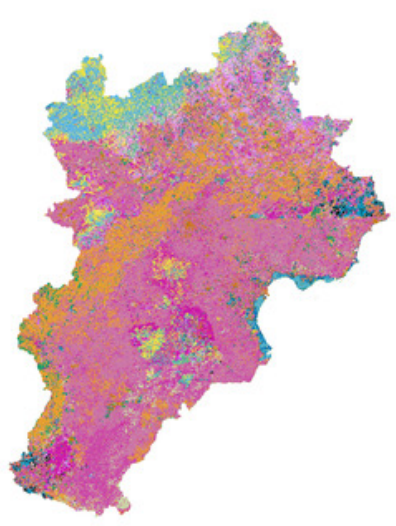

(b)

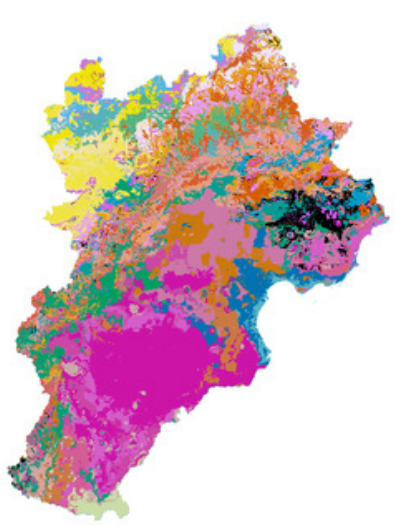

(e)

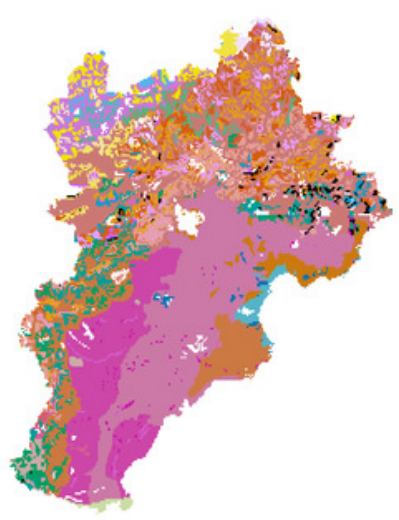

(c)

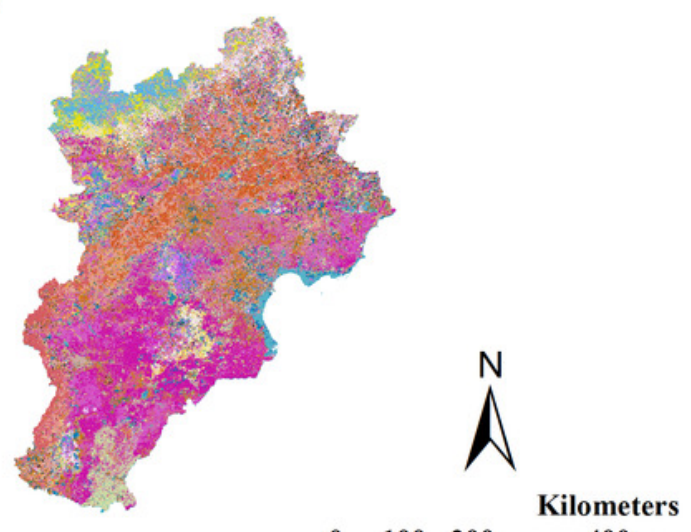

$\begin{array}{llll}0 & 100 & 200 & 400\end{array}$

Legend

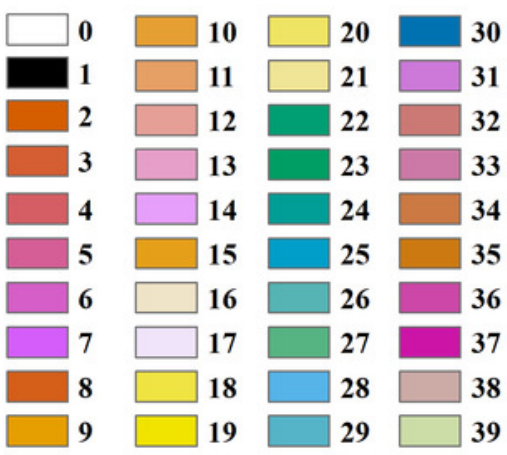

